\title{
Effect of Moringa Oleifera Leaves Meal or Its Combination with Phytase Enzyme on Nutrient Digestibility of Broiler
}

\author{
Fida Noor Baloch* Atteque Liaquat Baloch Nadir khan Baloch Abdul khalique Samejo \\ Naseebullah Marri Baloch Najeeb Ullah Dummar Ismail Anwer Baloch \\ Department of Animal Nutrition, Faculty of Animal Husbandry and veterinary Sciences Sindh Agriculture \\ University, Tandojam, Pakistan
}

\begin{abstract}
Moringa oleifera leaves meal are good source of amino acids, Vitamins, and it has medicinal uses also are rich in carotene level and ascorbic acid with a good amino acid profile its leaves given with combination of Phytase enzyme because Poultry required enzymes which help in feed breakdown because chicken have not enzyme for fibres break down. The using of enzyme have many benefits in poultry diets include not only enhanced feed conversion, performance and nutrient digestibility. The present study was undertaken in order to determine the effect of Moringa oleifera leaves meal or its combination with phytase enzyme on nutrient digestibility of broiler. Two hundred day-old Ross broiler chicks from a commercial hatchery were purchased \& after initial weight; birds were arbitrarily separated in groups, i.e. A (control) was offered $0 \%$ Moringa oleifera meal whereas; $1.25 \%$ (group B), $2.5 \%$ (group C) and 3.75\% (group D) moringa oleifera leaves meal and with combination of 0 $\mathrm{g} / \mathrm{kg}$ group A (control), $0.025 \mathrm{~g} / \mathrm{kg}$ (group B), $0.075 \mathrm{~g} / \mathrm{kg}$ (group C) and $0.05 \mathrm{~g} / \mathrm{kg}$ (group D) phytase enzyme provided in broiler feed. Parameters which selected in present research work as, weight gains, feed intake, water intake, feed conversion ratio nutrient digestibility calculated. The results shows that feed intake was significantly higher in group A followed by group B, group $\mathrm{C}$, and group D (g/chick), the higher water intake was recorded in group A, followed by other treated groups B, C and D. Live body weight gain was significantly higher in group $\mathrm{C}$ followed by group A, group $\mathrm{B}$, and group $\mathrm{D}$ (chick). Feed conversion ratio was significantly $(\mathrm{p}<0.05)$ better in group C, followed by group A, B and group D. Furthermore, crude protein digestibility starter/finisher was recorded significantly higher in group C followed by control group A, group B and group D. Metabolizable energy starter/finisher was Maximum in group C followed by control (A), group B and group D.
\end{abstract}

Keywords- Broiler birds, Moringa oleifera, phytase enzyme, body weight gain, nutrient digestibility.

DOI: $10.7176 / \mathrm{JBAH} / 11-10-04$

Publication date:May $31^{\text {st }} 2021$

\section{INTRODUCTION}

The poultry sector one of the highest energetic sections in different organized of the industries of agriculture in Pakistan. The industries of poultry are facing some problems in early growth and active biological activities as per the requirement of the market for enhancing the socio-economic status of the poultry oriented community in the under developing country.

Moringa oleifera leaves meal contains $86-87 \%$ DM, $29.8 \%$ CP, $27.8 \%$ calcium, $22.4 \%$ CF, $4.39 \%$ EE, $0.26 \%$ phosphorus and negligible amount of tannin [1]. Moringa oleifera leaf $2.23 \%$, carbohydrates $43.88 \%$, moisture $76.53 \%$, caloric value $1296.00 \mathrm{~kJ} / \mathrm{g}$, ash $7.13 \%$, Calcium and Iron content were 28.29 . On dry base the protein content of MOLM is $20-35 \%$ and maximum significant in all the essential amino acids the protein is high quality having important quantity [2]. It is extensively nurtured, especially East and Africa in the tropical areas of dry places and also located within various tropics of different countries of the world, because its seed of it and its leaves and useful fodder, seeds, vegetable, and plant growth.

Natural nutrition of the tropics the Moringa oleifera plant is a significant food product which has had huge consideration. In many countries of the world Pakistan, India, Philippines Hawaii, USA and many parts of Africa. All parts of MOLM are importance and benefits for poultry and animal nutrient like seeds, leaves, flowers and fruits are used [3].

The cost amount of feed to a significant proportion of comprehensive livestock production system [4]. According to a report that, cost of feed represents up to $60 \%-80 \%$ of the whole broiler chicken production cost [5]. Sunflower, which is one of the conventional feed resource and used for the purpose of animal protein and poultry diets due to unavailability of cheaper alternative protein sources in many countries. Fig. 1. (A).

Poultry required enzymes which help in fed breakdown because chicken have not enzyme for fiber break down. Enzymes which are biological catalyst composed of amino acids with minerals and vitamins. The using of enzyme have many benefits in poultry diets include not only enhanced feed conversion and bird performance but also reduced output of excreta problems of environment. It is common practice to name enzymes by adding the suffixase and protease which breakdown protein, pancreatic lipase which splits lipid /fat. Those enzymes added to feed as a supplement are exogenous $[6,7]$. In nutrient of poultry the enzyme usage in animal feed have great importance Fig. 1. (B). 
In most of the developing countries in the price of feed ingredients has been a major constriction. As a consequence nonconventional feed ingredients and cheaper have to be used which contain higher percentage of insoluble/crude fiber and soluble beside with starch. Non Starch Polysaccharides are polymeric carbohydrates which differ in structure from starch and composition [8] and possess chemical cross linking among them therefore, poultry are not well digested well [9]. In the intestinal tract part of these Non-Starch Polysaccharides is water-soluble which is notorious for forming a gel like viscous consistency [10] thus gut performance reducing. Phytase enzyme use in the feed industry enzymes in the feed industry have mostly been used for poultry to neutralize the effects in cereals viscous, polysaccharides. These antinutritive carbohydrates are undesirable, as in the diet they reduce absorption and digestion of all nutrients, especially protein and fat. Phytase enzyme not only increases the availability of phosphate in plants and also decreases pollution of environmental. Several other enzyme products are currently being evaluated in the poultry feed industry to assist in the digestion of starch in early-weaned animals and to neutralize certain antinutritive factors in noncereal feedstuffs. The phytase enzyme reduces the inorganic phosphorus quantity ( $40 \%$ in broilers) which needed in poultry diet, in environment decreases the excreted amount makes more phosphorus available for the bird [11]. The importance of enzyme using in animal feed. Recently, considerable attention has been shown as a feed phytase enyme in combination with poultry feed. The current mission was scheduled to carry out the influence of partial replacement of sunflower with phytase enzyme on nutrient digestibility of broiler.

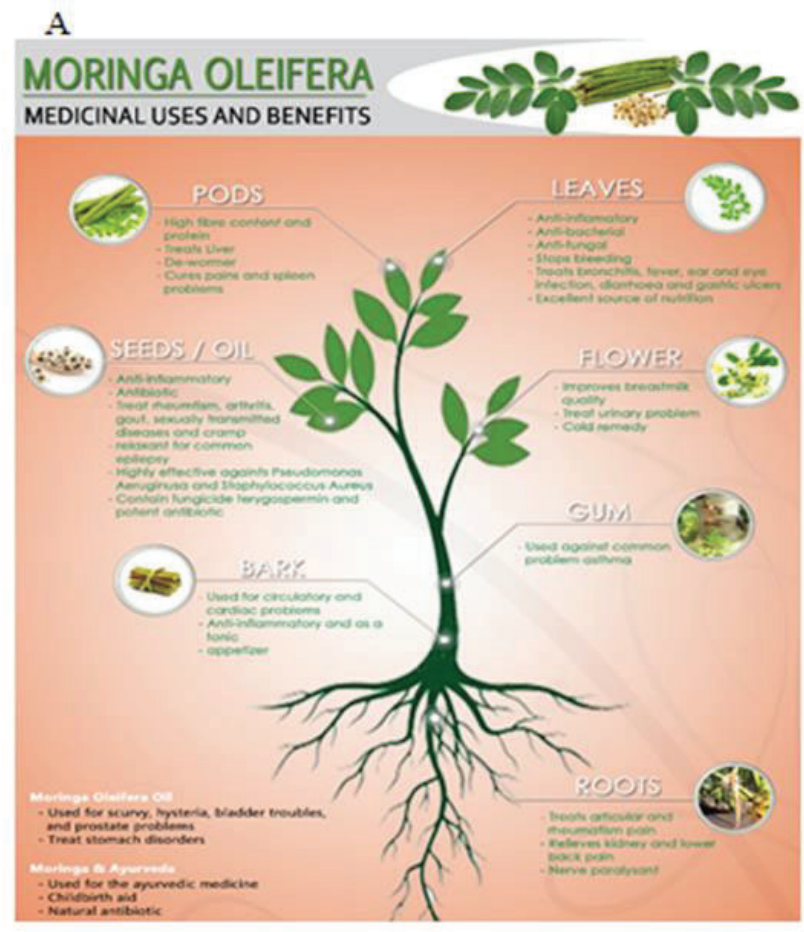

B

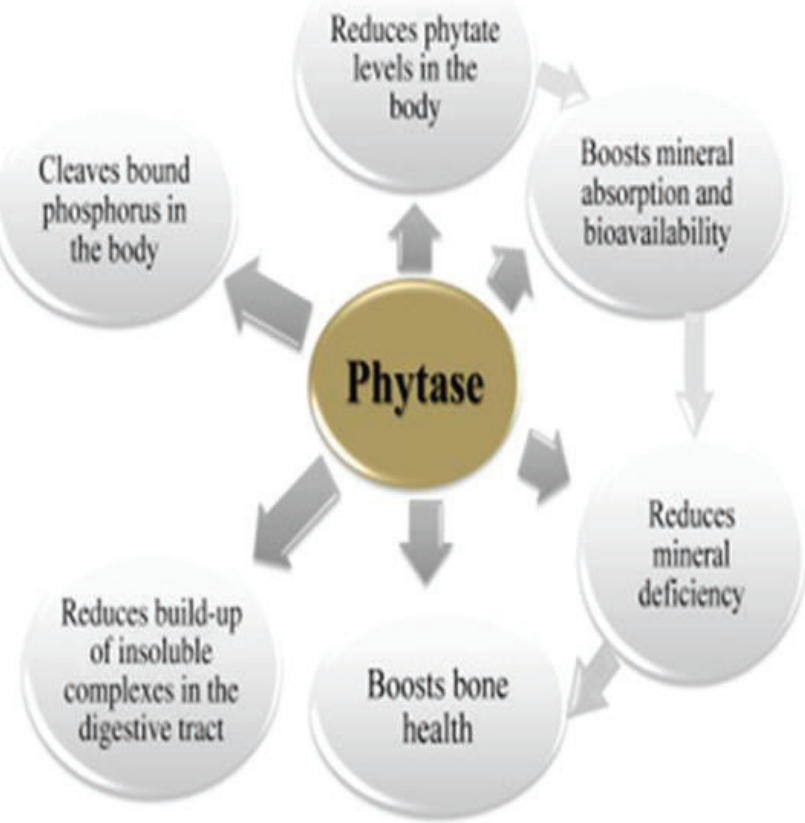

Fig. 1. (A). All parts of MOLM are importance and benefits for poultry

(B). In nutrient of poultry the enzyme usage and great importance

\section{Materials and Methods}

The experiment was carried out at the Poultry Research Unit of the Department of Poultry Nutrition, Sindh agriculture university, Tandojam, Pakistan, with the approval of the Committee for Animal Experiments of the Institution.

\subsection{Phytase for poultry feed industry}

Phytase enzyme which are produced commercially for utilization and improve nutrient digestibility added to poultry feeds. In the poultry feed industry ideal phytase enzyme is acidic pH unaffected and in the small intestine and stomach, where is cost-effective to produce, phosphorus absorption takes place and high temperatures resistant $\left(65-80^{\circ} \mathrm{C}\right)$, through feed pelleting are encountered [9]. In many others scientist and scholar's research focused on the testing of efficacy and identification of the former for use of Phytase enzyme in the animal feed industry ability to hydrolyze Phytic acid in the gastro intestinal tract [5].

\subsection{Microbial phytase enzyme activity sites}

In poultry the site activity of microbial phytase enzyme at tract of poultry gastro intestinal sections. In 
proventriculus and crop followed by the jejunum and duodenum of poultry have greater activity of a microbial phytase (fungal phytase) and irrelevant action in the ileum [10].

\subsection{Experimental birds and housing}

Two hundred day-old Ross broiler chicks from a commercial hatchery were purchased \& after initial weight; birds were arbitrarily separated in groups, i.e. A (control) was offered $0 \%$ Moringa oleifera meal whereas; $1.25 \%$ (group B), 2.5\% (group C) and 3.75\% (group D) moringa oleifera leaves meal and with combination of 0 $\mathrm{g} / \mathrm{kg}$ group A (control), $0.025 \mathrm{~g} / \mathrm{kg}$ (group B), $0.075 \mathrm{~g} / \mathrm{kg}$ (group C) and $0.05 \mathrm{~g} / \mathrm{kg}$ (group D) phytase enzyme provided in broiler feed. Tab.1.

Tab. 1. Experimental birds design and housing

\begin{tabular}{lcccc}
\hline Iroups & A & B & C & D \\
\hline \multirow{3}{*}{$\begin{array}{c}\text { Supplementation } \\
\text { Nasil }\end{array}$} & $\begin{array}{c}1.25 \% \\
\text { diets }\end{array}$ & $\begin{array}{c}\text { MOLM }+0.025 \\
\text { Physe enzyme } \\
\text { g/kg of Feed }\end{array}$ & $\begin{array}{c}5 \% \text { MOLM }+0.075 \\
\text { hytase enzyme g/kg } \\
\text { of Feed }\end{array}$ & $\begin{array}{c}3.75 \% \text { MOLM }+0.05 \\
\text { Phytase enzyme g/kg } \\
\text { of Feed }\end{array}$ \\
\hline
\end{tabular}

2.4. Feed intake $(g)$

Feed was given twice a day, the feed which refused was collected daily to each group chickens ad libitum. Fig. 2.

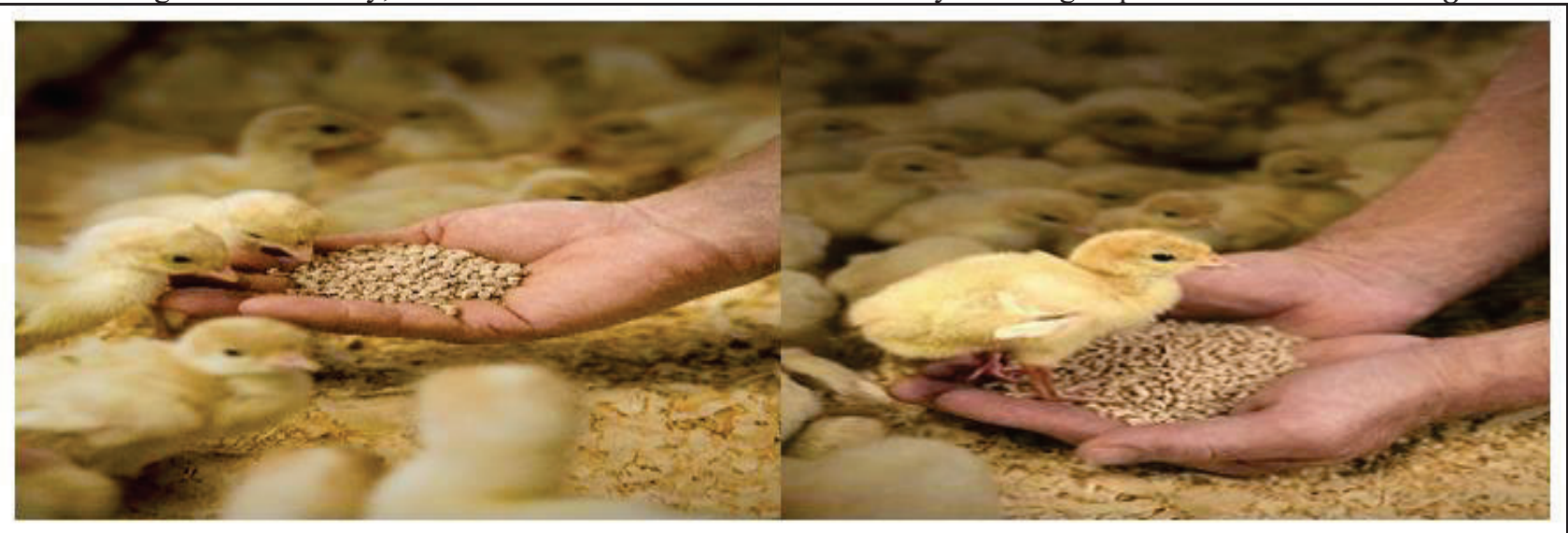

Fig. 2. The feed given twice a day which refused was collected daily and finally consumed feed was recorded using the formula bellow;

$$
\text { Feed intake }(\mathrm{g})=\frac{\text { Total feed offered }- \text { Total feed intake }}{\text { Total broiler }} \times 100
$$

\subsection{Body live weight $(\mathrm{g} / \mathrm{b})$}

Before the research work, by electric weight balance chicken were weighed. In every week the birds were randomly selected from each group and weighed during experimental duration. Fig.3. 


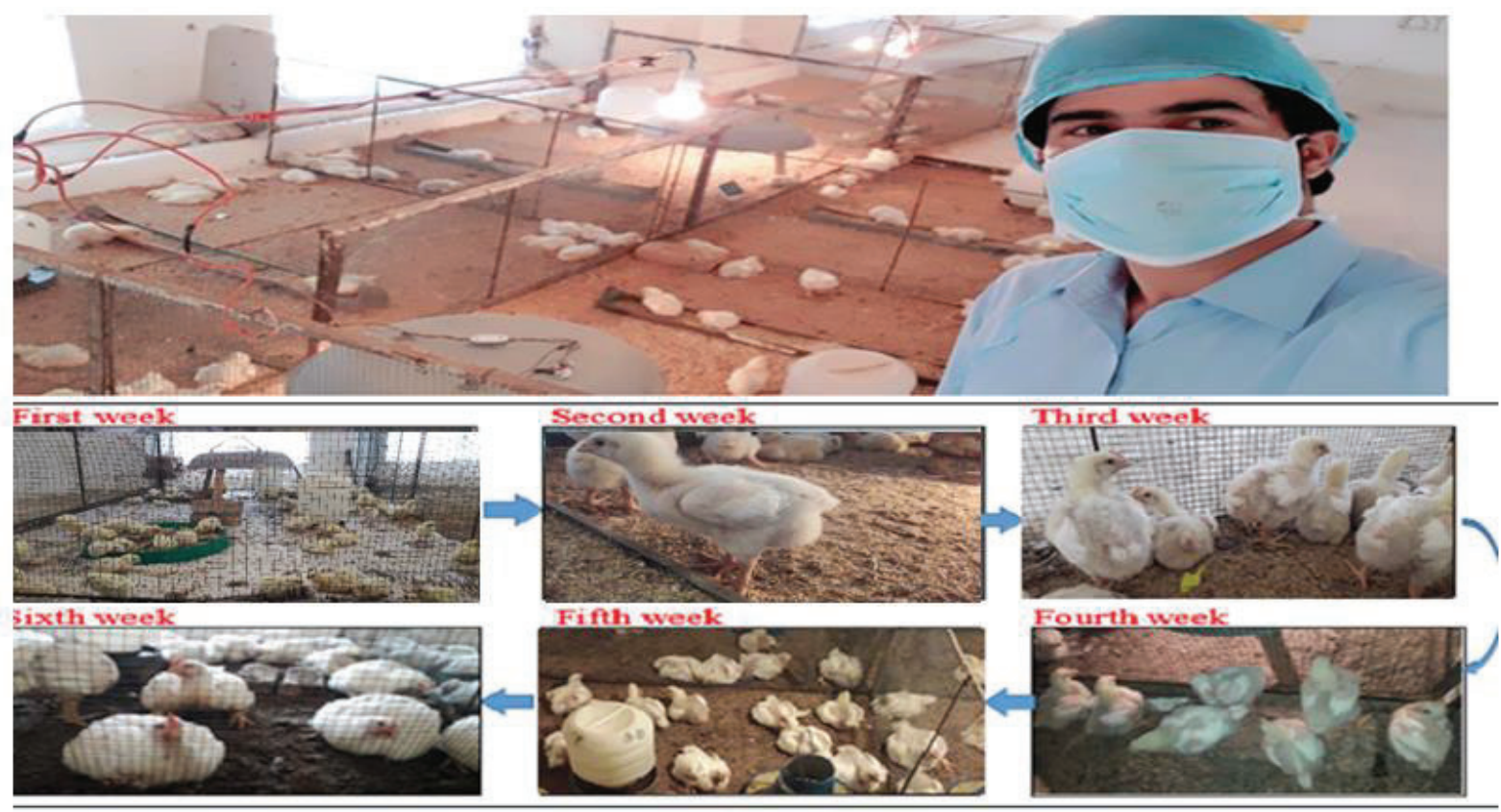

Figure. 3. Different stages of live body gain of broiler chicks calculated in first week to sixth weeks

2.6. F.C.R (\%)

To calculate FCR, increasing weight and intake of feed, were noted by following formula;

\section{FCR $=$ Total feed consumed $\times 100$ Total weight gain}

2.7. Nutrient digestibility (\%)

Digestibility is estimated from the determined values as follow

$$
=100-100\left\{\frac{\% \text { maker in diet }}{\% \text { maker in faces }} " \frac{\% \text { nutrient in feaces }}{\% \text { nutrient in fees }}\right\}
$$

\subsection{Mortality percentage (\%)}

Died chicken were observed during research, finally the mortality \% noted by formula below;

$$
\text { Mortality (\%) }=\frac{\text { Chicken died }}{\text { No. of chicken (reared) }} \times 100 \text { (Eq. 4) }
$$

\subsection{Data analysis}

In Microsoft excel the data was formulated then further analyzed in One-way analysis of difference (ANOVA) through (statistix 8.1 software) and significant variances were associated using the LSD examination procedure $(\mathrm{P}<0.05)$.

\section{Ration Formulation (starter/finisher)}

Ration

Initially, the chicks were offered commercial starter/finisher ration. The starter ration was supplied for first three weeks and finisher ration was given for last three weeks. Poultry ration were formulated as Tab.2-3, according to the recommendation of NRC (1994). 
Tab.2. Ingredients and formulation of basal diet (Starter/kg).

\begin{tabular}{lrrrr} 
Ingredients & \multicolumn{4}{c}{ Starter $/ \mathrm{kg}$} \\
$\quad$ Groups & \multicolumn{2}{c}{$\mathrm{B}$} & $\mathrm{D}$ & \\
Rice Broken & 31.3 & 31.3 & 31.3 & 31.3 \\
Maize & 30.5 & 30.5 & 30.5 & 30.5 \\
Fish meal & 6.5 & 6.5 & 6.5 & 6.5 \\
Soy bean meal & 24.4 & 24.4 & 24.4 & 24.4 \\
Sunflower meal & 5 & 3.72 & 2.5 & 1.2 \\
Moringa oleifera meal & 0 & 1.25 & 2.5 & 3.75 \\
Molasses & 0.55 & 0.55 & 0.55 & 0.55 \\
Lime stone & 0.55 & 0.55 & 0.55 & 0.55 \\
Salt & 0.25 & 0.25 & 0.25 & 0.25 \\
Soda Bi Carbonate & 0.01 & 0.01 & 0.01 & 0.01 \\
Premix Vitamin & 0.05 & 0.05 & 0.05 & 0.05 \\
Premix Minerals & 0.05 & 0.05 & 0.05 & 0.05 \\
Dietary Methionine & 0.32 & 0.32 & 0.32 & 0.32 \\
L-Methionine & 0.05 & 0.05 & 0.05 & 0.05 \\
Lysine Sulphate & 0.35 & 0.35 & 0.35 & 0.35 \\
L-Threonine & 0.09 & 0.09 & 0.09 & 0.09 \\
Diclazulin & 0.02 & 0.02 & 0.02 & 0.02 \\
Antibiotics & 0.01 & 0.01 & 0.01 & 0.01 \\
Phytase enzyme & 0 & 0.03 & 0.075 & 0.05 \\
Over-all & 100 & 100 & 100 & 100
\end{tabular}

Tab .3. Ingredients formulation of $\operatorname{diet}$ (Finisher/kg).

\begin{tabular}{|c|c|c|c|c|}
\hline Ingredients & Finisher/kg & & & \\
\hline Groups & A & B & C & D \\
\hline Rice Broken & 25.6 & 25.6 & 25.6 & 25.6 \\
\hline Maize & 38 & 38 & 38 & 38 \\
\hline Fish meal & 6.5 & 6.5 & 6.5 & 6.5 \\
\hline Soya bean meal & 21.6 & 21.6 & 21.6 & 21.6 \\
\hline Sunflowermeal & 5 & 3.73 & 2.5 & 1.25 \\
\hline Moringa oleifera meal & $\mathbf{O}$ & 1.25 & 2.5 & 3.75 \\
\hline Molasses & 0.3 & 0.3 & 0.3 & 0.3 \\
\hline Oil & 1.38 & 1.38 & 1.38 & 1.38 \\
\hline Lime stone & 0.4 & 0.4 & 0.4 & 0.4 \\
\hline Salt & 0.19 & 0.19 & 0.19 & 0.19 \\
\hline Soda Bi Carbonate & 0.08 & 0.08 & 0.08 & 0.08 \\
\hline Premix Vitamin & 0.05 & 0.05 & 0.05 & 0.05 \\
\hline Premix Minerals & 0.05 & 0.05 & 0.05 & 0.05 \\
\hline Dietary Methionine & 0.31 & 0.31 & 0.31 & 0.31 \\
\hline L-Methionine & 0.05 & 0.05 & 0.05 & 0.05 \\
\hline Lysine Sulphate & 0.38 & 0.38 & 0.37 & 0.37 \\
\hline L-Threonine & 0.1 & 0.1 & 0.1 & 0.1 \\
\hline Diclazulin & O - & - & - & \\
\hline Antibiotics & 0.01 & 0.01 & 0.01 & 0.01 \\
\hline Phytase enzyme & O & 0.025 & 0.075 & 0.005 \\
\hline TOTAL & 100 & 100 & 100 & 100 \\
\hline
\end{tabular}




\section{RESULTS AND DISCUSSION}

In current study, feed intake, live body weight, feed conversion ratio and nutrient digestibility was observed high in supplementation of phytase enzyme in different treatment groups as compare to control.

\subsection{Body Weight.}

Analysis of variance showed that there were significant differences between the weight of birds amongst the four treatments $(\mathrm{P}<0.01)$. The results of body weight of birds were noted in treated groups which were supplemented of phytase enzyme compared with un-supplemented group A. The maximum chicken body weight was noted in group $\mathrm{C}$, as compare to group $\mathrm{B}$. The average body weight was further decreased in group D and minimum in group $\mathrm{A}$ (control). The presence of phytase enzyme in group $\mathrm{C}$ diet recorded significantly $(\mathrm{P}<0.05)$ the maximum body weight gain Fig. 4 (A).

In instances where phytase enzyme is supplemented, the higher body weight gain may be attributable to an increase in $\mathrm{P}$ availability and, maybe feed intake [14]. According to [15], that the higher CP (crude protein) content may be due to greater content of crude fiber (CF), which may impair nutrient absorption and digestion while the reduced weight gain of broilers fed the control diet group A may be ascribed to low crude protein content of the diet compared to other diets.

\subsection{Feed intake.}

The intake of feed was analysis in different groups of chicks the feed intake was maximum in group A, as compare to treatments groups. The average intake of feed was further decreased in group C. Feed intake was minimum in group C. The results showed that in group A feed intake was higher than group C, B and D, Fig. 4 (A). In view of investigation the visible increase in feed intake might be attributed to increased largeness of the feed and metabolizable energy concentration of the diets. In instances where phytase enzyme is added, to rise in $\mathrm{P}$ availability and, may be feed intake [14]. According to [15] that unpalatability nature of a feedstuff will consequently inhibit chicks from consuming adequate quantity of the feed.

\subsection{Water intake ( $\mathrm{ml} / \mathrm{bird})$.}

The water intake of different groups. The maximum water intake was recorded in group A (control) and minimum in treated group C. Statistical analysis showed that, there were two groups (B and D) in which the means were non- significantly different from one another while group $\mathrm{C}$ was significantly different from control group as well group B and D, respectively.

The results shows that in group A (control) water intake was higher than group B, C and group D, respectively Fig. 4 (A).

\subsection{FCR \%.}

The FCR of different groups were examined and the FCR was minimum in treatment group C and in group B was higher than treatments groups the non-significantly variance founded respectively, Fig. 4 (B). This was in agreement with the report by [16], that non-conventional feed stuff often decreases feed cost. This confirms that there is better economic gain by feeding Phytase enzyme to broilers since it has the potential of reducing feeding cost of broilers. This supports the conclusion of several researchers that leaf meal supplementation in poultry rations has been proved as means of reducing cost and improving profit margin.

\subsection{Dressing percentage (\%)}

The dressing percentage of different groups were examined and the results are shown in Fig. 4 (B). The average dressing percentage of control (A) was noted minimum followed by B, C and D, respectively.

The results shows that maximum dressing percentage chick was in treated group. Statistical analysis showed all four means were significantly different from one another.

\subsection{Mortality percentage (\%)}

Mortality percentage of broiler chicks in different treatment groups supplement with Moringa oleiferia leaves with combination of Phytase enzyme are presented in Fig.4 (B). There were non-significantly different from one another.

In control group A, where the mortality rate was noted higher than rest of treatment groups, respectively. 


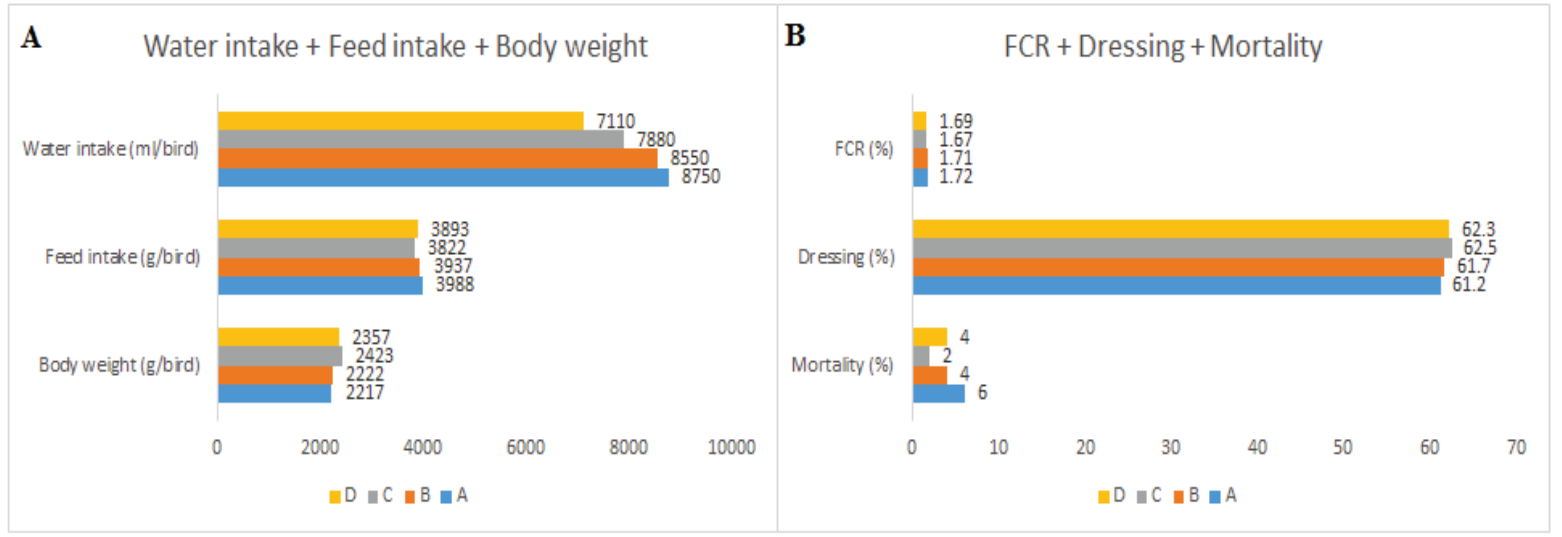

Fig. 4. (A). Water intake (ml/bird) + Feed intake (g/bird) + Body Weight ( $\mathrm{g} /$ bird $)$

(B). FCR (\%) + Dressing (\%) + Mortality (\%).

\subsection{Digestibility percentage.}

4.7.1. Crude proteins (\%)

The average crude proteins digestibility starter/finisher of control group (A) was noted, it was increased in different groups when they supplied Moringa oleifera with the combination of Phytase enzyme on broiler feed. The average crude protein digestibility of treatment groups B, C and D were noted Fig. 5, during starter and finisher phase. Statistically all four groups means were significantly different (starter/finisher) from one another. 4.7.2. Metabolizable energy (\%)

The average metabolizable energy starter/finisher of control (A) group, metabolizable energy was increased in different treated groups when supplied Phytase enzyme in feed of broiler.

The average metabolizable energy of different treatment groups B, C and D were noted Fig. 5. Statistically all four groups means were significantly different (starter/finisher) from one another. Metabolizable energy was increased in different groups when they had taken Phytase enzyme in broiler fed. The velocity at which the diet passes the digestive tract is a crucial digestion parameter, which differs on the basis of dietary fiber levels [19] Polyphenols have properties that may inhibit digestive enzymes and reduce digestibility [18]. Moreover, plant additives are assumed to have a positive impact on nutrient digestibility due to reduced competition for nutrients between the bird and its gut micro-flora.

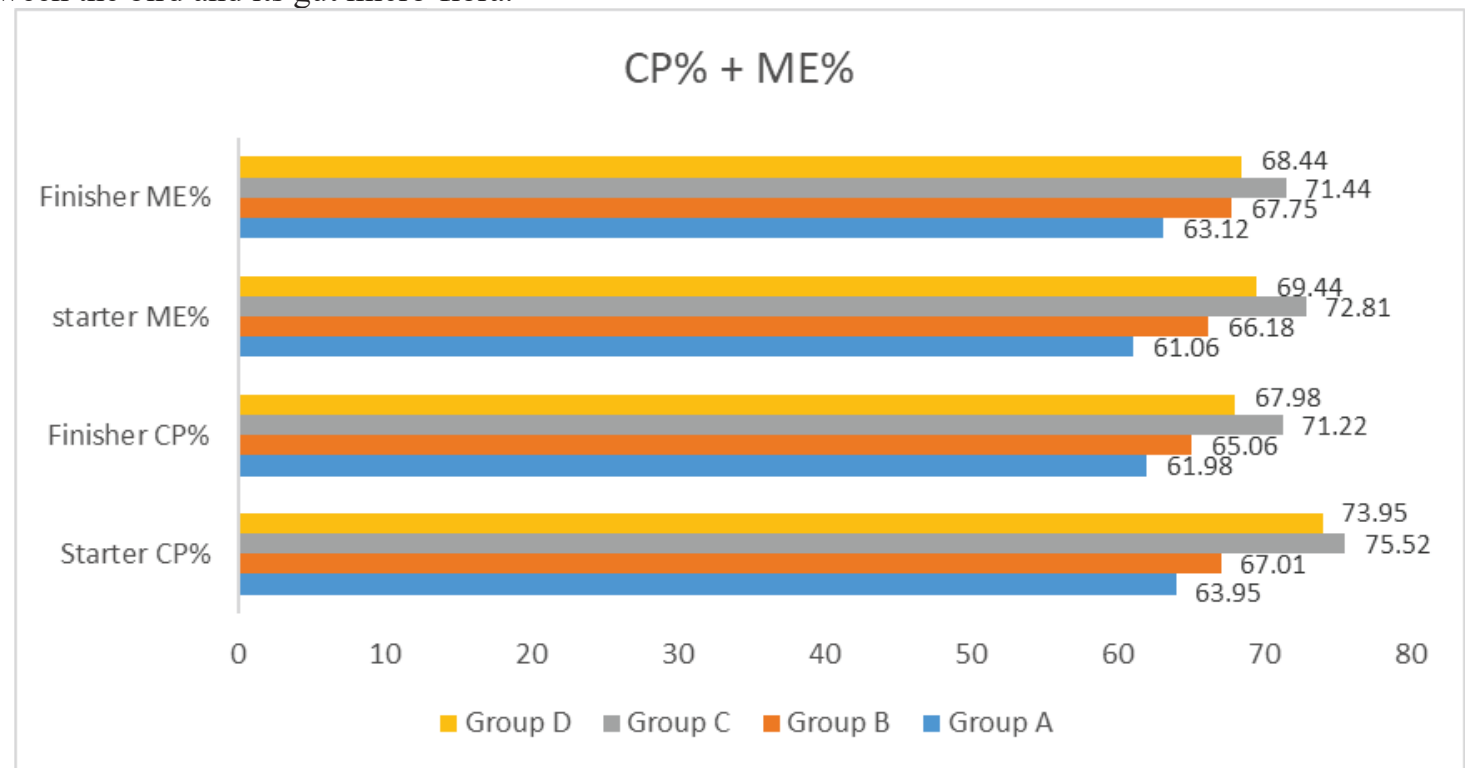

Fig. 5. CP\% and ME\% digestibility results Starter/Finisher of broiler

\section{CONCLUSIONS}

It is concluded from present study that, $2.5 \%$ Moringa oleiferia leaves with $0.075 \mathrm{~g} / \mathrm{kg}$ Phytase enzyme showed to be more profitable as compared to rest of the treatments groups B, D and control group (A). The broiler birds supplemented with Moringa oleifera combination with phytase enzyme resulted more nutrient digestibility and gain of chickens body weight by lower feed conversion ratio (cost of feed save) than other treatments. 


\section{SUGGESTIONS:}

On the basis of conclusion it could be suggested:

- For better conversion ratio, the broiler feed may be added with supplementation of $2.5 \%$ Moringa oleiferia leaves with combination of $0.075 \mathrm{~g} / \mathrm{kg}$ Phytase enzyme.

- Moreover, the research may be carried to investigation the influence of $2.5 \%$ Moringa oleiferia leaves with combination of $0.075 \mathrm{~g} / \mathrm{kg}$ Phytase enzyme on the growth performance, nutrients digestibility in other avian species.

\section{References}

[1] Kakengi, A.M.V., Shen, M.N. Sarvert, S.V. and Fujihara, T. (2003), "Can Moringa oleifera be used as protein supplement to ruminant diet". Asian - Australian Journal of Animal Science 18 (1): 42 - 47.

[2] Foidl, N., \& Paull, R. (2008). Moringa oleifera. The Encyclopedia of fruit and nutrition. ABI, Oxfordshire, 509-512.

[3] Anwar, F., Latif, S., Ashraf, M., \& Gilani, A. H. (2007). Moringa oleifera: a food plant with multiple medicinal uses. Phytotherapy Research: An International Journal Devoted to Pharmacological and Toxicological Evaluation of Natural Product Derivatives, 21(1), 17-25.

[4] Ekenyem, B. U., \& Madubuike, F. N (2001), Non-ruminant livestock production in the tropics. Gust Chucks Graphics Center, Owerri, Nigeria, 120-145.

[5] Pandey A, Szakacs G, Soccol C R, Rodriguez-Leon J A, Soccol V T. 2001. Production, purification and properties of microbial phytases. Review paper. Bioresource Technol. 77: 203-214.

[6] Classen, H. L., (1996). Successful application of enzymes relies on knowledge of the chemical reation to be affected and conditions under which the reaction will occur. Feed Mix 4: 22-28.

[7] Classen, H. 1., M. R. Bedford. (1991). the use of enzymes to improve the nutritive value of poultry feed. In recent advances in animal nutrition. (eds. W. Haresign and D. J. A. Cole. Butterworth, London, pp79-102.

[8] Morgan, A.J. and M. R. Bedford. (1995). Advances in the development and application of feed enzymes. Australian Poultry Science Symposium 7: 109- 115.

[9] Adams, E.A. and R. Pough. (1993). Non-starch polysaccharides and their digestion in poultry. Feed Compounder 13: 19-21.

[10] Ward, N.E. (1995). With dietary modifications, wheat can be used for poultry. Feedstuffs 7 Aug, 1416.

[11] Simons, P.C.M. and H. A. J. Versteegh. (1991). Application of microbial phytase in poultry nutrition. Poultry Science 70: (Suppl. 1), 110.

[12] Lei X, Stahl C. (2001). Biotechnological development of effective phytases for mineral nutrition and environmental protection. Appl. Microbiol. Biotechnol. 57: 474-481.

[13] Yu B, Jan Y C, Chung T K, Lee T. T, Chiou P W S. 2004. Exogenous phytase activity in the gastrointestinal tract of broiler chickens. Anim. Feed Sci. Technol. 117: 295-303.

[14] Rao, S. V. R., Reddy, V. R. and Reddy, V. R. (1999). Enhancement of phytate phosphorus availability in the diets of commercial broilers and layers. Anim. Feed Sci. Tech. 79: $211-222$.

[15] Onu, P.N and Otuma, M.O. (2008), "Utilization of heat-treated sheep dropping in the diets of broiler finisher chicks". International journal of Poultry science, 8 (10: 995 - 998.

[16] Omekam V.N (1994), Studies on nutrition and health implication of dietary inclusion of dried poultry waste for broiler. MSc Thesis, Federal University of Technology; Owerri, Nigeria 41.

[17] Issa, K.J., and Omar, J.M.A. (2012). Effect of garlic powder on performance and lipid profile of broilers. Open Journal of Animal Sciences, 2 (2): 62-68.

[18] Hernández, F., Garci'a, V. Madrid, J. Orengo, J. Catala', P. and Megi'as, M.D. (2006). Effect of formic acid on performance, digestibility, intestinal histomorphology and plasma metabolite levels of broiler chickens. British Poultry Science, 47 (1): 50 - 56.

[19] Liu, N., Ru, Y.J. Tang, D.F. Xu, T.S and Partridge, G.G. (2010). Effects of corn distillers dried grains with solubles and xylanase on growth performance and digestibility of diet components in broilers. Animal Feed Science and Technology, 163: 260-266 